\title{
TINJAUAN TERHADAP SISTEM MULTI PARTAI DALAM SISTEM PEMERINTAHAN PRESIDENSIAL DI INDONESIA PADA ERA REFORMASI
}

\author{
Zuhdi Arman ${ }^{1}$
}

\begin{abstract}
ABSTRAK
Perubahan Undang-Undang Dasar 1945 yang terjadi di era reformasi didasari komitmen untuk mempertegas sistem Presidensial. Sebaliknya, sistem multi partai yang dikombinasikan dengan sistem pemerintahan Presidensial saat ini mendorong partai untuk membentuk koalisi yang justru memperlemah sistem presidensial itu sendiri. Praktik koalisi di Indonesia yang dibentuk sebelum pemilihan umum Presiden dan Wakil Presiden didominasi transaksi politik mengenai pembagian jabatan pemerintahan tanpa disertai perumusan platform bersama. Kenyataannya, koalisi yang dibentuk tidak menjamin bahwa partai-partai yang tergabung dalam koalisi yang memiliki wakil di badan legislatif akan selalu mendukung program-program pemerintah. Oleh karena itu, penelitian ini ditujukan untuk memahami penerapan sistem multi partai dalam sistem pemerintahan Presidensial di Indonesia pada era reformasi sekaligus merumuskan implikasi terhadap hubungan eksekutif dan legislatif serta penerapan yang idealnya. Jenis penelitian ini dapat dapat di golongkan dalam jenis penelitian yuridis normatif, karena menjadikan bahan kepustakaan sebagai tumpuan utama. Sumber data yang digunakan, bahan hukum primer, bahan hukum sekunder, dan bahan hukum tertier. Teknik pengumpulan data dalam penelitian ini dengan menggunakan metode kajian kepustakaan. Hasil penelitian menunjukkan bahwa penerapan sistem multi partai dalam sistem pemerintahan Presidensial justru memperlemah sistem Presidensial dan memiliki implikasi terhadap relasi eksekutif dan legislatif. Tiga hal yang menjadi implikasinya yaitu; Pertama, banyaknya kepentingan partai politik yang bertentangan dengan kebijakan pemerintah. Kedua, tidak adanya pengaturan koalisi tetap. Ketiga, lemahnya posisi Presiden. Idealnya penerapan sistem multi partai, agar terciptanya stabilitas sistem pemerintahan Presidensial di Indonesia, maka ada 3 (tiga) hal yang perlu dibenahi dalam sistem Presidensial kita, yaitu: Pertama, penyederhanaan partai politik, kedua, pengaturan koalisi tetap, dan ketiga, penguatan desain institusi kepresidenan. Penulis menyarankan diperlukan adanya koalisi partai politik yang sifatnya permanen yang ditetapkan melalui aturan-aturan, undang-undang yang lebih jelas sehingga akan menghasilkan pemerintahan yang kuat dan efisien dan diupayakan adanya penguatan institusi kepresidenan agar posisi Presiden tidak lemah terhadap Parlemen, dengan cara pemisahan institusi kepresidenan dari Dewan Perwakilan Rakyat (DPR) dan partai politik melalui aturan-aturan Undang-Undang yang jelas.
\end{abstract}

Kata Kunci: Sistem Multi Partai, Koalisi, Sistem Presidensial.

Dosen Program Studi Ilmu Hukum, Fakultas Sosial Dan Humaniora, Email: zuhdiarman@yahoo.co.id, 


\begin{abstract}
Amendment Act of 1945 that occurred in the era of reform based on a commitment to reinforce the Presidential system. In contrast, multi-party system in combination with the current presidential system of government is to encourage parties to form a coalition that actually weakens the presidential system itself. Practices in Indonesian coalition formed before the general election of President and Vice President dominated political dealings regarding the division of public office without the formulation of a common platform. In fact, the coalition was formed not ensure that parties who are members of the coalition that has a representative in the legislature will always support government programs. Therefore, this study aimed to understand the application of multi-party system in the Presidential system of government in Indonesia in the reform era at once formulate implications for the executive and legislative relations and the implementation of the ideal. This type of research can be can be classified into types of normative juridical research, because it makes the literature as the main focus. Source of data used,the primary legal materials, secondary law, and tertiary legal materials. Data collection techniques in thisstudy using the method of literature study. The results showed that the application of multi-party system in the Presidential system of government actually weaken the presidential system and have implications for the executive and legislative relations. Three things that the implications are; First, the number of political parties' interests that conflict with government policy. Second, the absence of permanent coalition arrangement. Third, the weak position of President. Ideally the implementation of a multi-party system, in order to create stability in the Indonesian presidential system of government, then there are three (3) things that need to be addressed in our Presidential system, namely: First, the simplification of the political parties, the second, setting the coalition remains, and the third, the strengthening of institutional design presidency. The author suggests needed coalition of political parties that are permanently defined by the rules of Law clearer so that it will produce a strong and efficient government.
\end{abstract}

Keywords: Multi-Party System, Coalition, a Presidential System.

\title{
I. PENDAHULUAN
}

Dalam perkembangan sejak kemerdekaan sampai dengan sekarang ini Indonesia merupakan Negara demokrasi, namun dalam perjalanan sejarah perwujudan demokrasi di Indonesia tidaklah berjalan dengan semestinya, sebagaimana sebuah Negara demokrasi. Dari awal pemerintahan Indonesia, dimana Presiden Soekarno sebagai kepala Negara dan sebagai kepala pemerintahan, menerapkan konsep Demokrasi Terpimpin, menilai Demokrasi Barat yang bersifat liberal tidak dapat menciptakan kestabilan politik.

Setelah jatuhnya pemerintahan Soekarno muncullah pemerintahan Orde Baru dimana Presiden Soeharto sebagai kepala Negara dan sebagai kepala pemerintahan. Pada awalnya Orde Baru dapat menampilkan pemerintahan yang demokratis tetapi ternyata hal itu hanya berlangsung kira-kira selama 3 tahun yakni selama pemerintah 
baru ini menyiapkan format politik baru melalui penyusunan Undang-Undang bidang politik. Setelah itu dan lebih-lebih setelah pemilu tahun 1971, pemerintah kembali otoriter. Otoriterisme Negara ini berlangsung terus hingga dijatuhkannya rezim Orde Baru oleh gerakan reformasi pada Juli $1998{ }^{2}$

Turunnya pemerintahan Soeharto merupakan awal dimulainya tahapan baru bagi masyarakat Indonesia, yang kemudian dikenal dengan era reformasi. Pada era reformasi, sistem Kepartaian Indonesia menganut sistem multi partai. Aturan ini tersirat dalam Pasal 6A ayat (2) UUD 1945 yang menyebutkan bahwa Presiden dan wakil Presiden diusulkan oleh partai politik atau gabungan partai politik. Frasa gabungan partai politik mengisyaratkan paling tidak ada dua partai atau lebih yang bergabung untuk mengusung seorang calon pasangan Presiden dan wakil Presiden dan bersaing dengan calon lain yang diusulkan partai-partai lain. Ini artinya sistem kepartaian di Indonesia harus diikuti oleh minimal tiga partai politik atau lebih. Sistem pemerintahan Presidensial telah dianut oleh Indonesia sejak masa Orde Lama sampai masa reformasi sekarang ini. Walaupun secara historis, Indonesia pernah gagal menerapkan sistem parlementer. Pasca Amandemen (perubahan) Undang-Undang Dasar 1945 mempertegas sistem Presidensial sebagai dasar penyelenggaraan Negara. ${ }^{3}$. Secara umum, sistem pemerintahan Negara Indonesia menganut "Sistem Presidensial" dijelaskan dengan terang dan sistematis dalam penjelasan Undang-Undang Dasar $1945 .^{4}$

Sistem pemerintahan Presidensial secara prinsipil menitikberatkan pada pemisahan kekuasaan secara berimbang. Eksekutif tidak memiliki wewenang untuk membubarkan parlemen (DPR). Sebaliknya, Presiden atau eksekutif pun tidak harus berhenti walaupun telah kehilangan dukungan dari mayoritas suara di parlemen (DPR). ${ }^{5}$

Scott Mainwaring mengemuka-kan tiga kelemahan koalisi jika dibentuk dalam sistem Presidensial. Pertama, dalam sistem Presidensial, Presiden membentuk sendiri kabinetnya, sementara partai politik mempunyai komitmen yang rendah dalam

\footnotetext{
Mahfud MD, M. Amandemen Konstitusi Menuju Reformasi Tata Negara. Yogyakarta: UII. 1999.

Mahmuzar. Sistem Pemerintahan Indonesia Menurut UUD 1945 Sebelum dan Sesudah Amandemen. Bandung: Nusa Media.

Tutik, T. T. Konstruksi Hukum Tata Negara Indonesia PascaAmandemen UUD 1945. Jakarta: Kencana. 2011.

Yulies Tiena Masriani. Pengantar Hukum Indonesia. Jakarta: Sinar Grafika. 2009.
} 2010. 
mendukung Presiden. Kedua, anggota legislatif dari partai politik yang mempunyai menteri di kabinet tidak mendukung pemerintah sepenuhnya. Ketiga, secara umum, keinginan partai politik membubarkan koalisi lebih kuat dalam sistem pemerintahan Presidensial. $^{6}$

Di parlemen, partai politik membawa visi dan misi partai sebagai bentuk kebijakan bagi publik dalam realisasi pemerintahan. Sehingga partai politik diparlemen tidak proporsional dalam melaksanakan tugas dan fungsinya, yaitu di dalam ke pemerintahan, baik dalam oposisi atau koalisi. ${ }^{7}$

Sistem Presidensial yang diterapkan Indonesia dapat menjadi bahasan yang menarik, dikarenakan pada umumnya Negara yang mengunakan sistem Presidensial hanya ada dua partai saja. Dapat dicontohkan di Amerika Serikat, hal ini sangat erat kaitannya terhadap penguatan pemerintahan, dimana ketika Presiden terpilih itu dari partai Demokrat maka secara otomatis partai Republik akan menjadi oposisi, begitupun sebaliknya demi terwujudnya cheks and balances oleh eksekutif dan legislatif. Hal yang berbeda yang dapat dilihat dari sistem Presidensial di Indonesia, dimana di Indonesia menerapkan sistem Presidensial yang tidak hanya berisi dua partai, tetapi banyak partai atau multi partai. Menarik sekali apabila mempertanyakan bagaimanakah seandainya Presiden terpilih itu berasal dari partai yang secara kumulatif minoritas diparlemen, walaupun mungkin itu partai besar, dapat dikatakan demikian, apakah partai-partai yang disatukan itu jumlahnya melebihi partai Presiden terpilih, akan secara otomatis menjadi oposisi? Apabila, demikian maka dapat dibayangkan betapa lemahnya kedudukan eksekutif dalam mejalankan roda pemerintahan.

Perdebatan mengenai sistem pemerintahan bukanlah mengenai sistem mana yang lebih baik, melainkan mengenai pilihan mana yang lebih tepat bagi suatu Negara berdasarkan struktur sosial, budaya politik dan sejarahnya, karena setiap sistem memiliki kelebihan dan kekurangan masing-masing.

Dari uraian di atas dapat diketahui sistem kepartaian dan sistem pemerintahan apa dan yang bagaimana yang diterapkan di Indonesia. Melihat teori serta fakta sejarah dimana sistem pemerintahan yang dianut oleh suatu Negara harus didukung dengan sistem kepartaian yang sesuai atau ideal dengan sistem pemerintahan tersebut sehingga 
terjadi keselarasan antara sistem pemerintahan dengan sistem kepartaian karena hal tersebut akan berdampak pada perwujudan sistem pemerintahan itu sendiri dalam rangka penyelenggaraan Negara yang baik. Menurut website: ${ }^{8}$ Sistem kepartaian adalah merupakan suatu organisasi yang bersifat nasional dan dibentuk oleh sekelompok warga negara Indonesia secara sukarela atas dasar kesamaan kehendak dan cita-cita untuk memperjuangkan dan membelakepentingan politik anggota, masyarakat, bangsa dan negara, serta memelihara keutuhan NKRI berdasarkan Pancasila dan UndangUndang Dasar 1945.

\section{Teori Demokrasi}

Demokrasi adalah bentuk atau sistem pemerintahan yang segenap rakyat turut serta memerintah dengan perantaraan wakilnya, atau disebut juga dengan pemerintahan rakyat, dan gagasan atau pandangan hidup yang mengutamakan persamaan hak dan kewajiban serta perlakuan yang sama bagi semua warga Negara. ${ }^{9}$ Dengan demikian demokrasi juga merupakan suatu sistem pemerintahan yang dilakukan dari rakyat, oleh rakyat dan untuk rakyat.

Secara umum terdapat dua bentuk demokrasi yaitu demokrasi langsung dan demokrasi perwakilan.

a. Demokrasi langsung

Demokrasi langsung merupakan suatu bentuk demokrasi dimana setiap rakyat memberikan suara atau pendapat dalam menentukan suatu keputusan. Dalam sistem ini, setiap rakyat mewakili dirinya sendiri dalam memilih suatu kebijakan sehingga mereka memiliki pengaruh langsung terhadap keadaan politik yang terjadi.Sistem demokrasi langsung digunakan pada masa awal terbentuknya demokrasi di Athena dimana ketika terdapat suatu permasalahan yang harus diselesaikan, seluruh rakyat berkumpul untuk membahasnya. Di era modren sistem ini menjadi tidak praktis karena umumnya populasi suatu Negara cukup besar dan mengumpulkan rakyat dalam satu forum merupakan hal yang sulit. Selain itu, sistem ini menuntut partisipasi yang tinggi dari rakyat sedangkan rakyat modren

\footnotetext{
8 www. Corina Auliya, R. F. F. (2017). www.dictio.id/t/jelaskan-mengenai-sistem-kepartaian-dan klasifikasinya/ 12483. Klasifikasi Sistem Kepartaian Yuhana A. Sistem KetatanegaraanIndonesia Pasca Perubahan UUD 1945. Bandung: Fokus Media. 2009.
} 
cendrung tidak memiliki waktu untuk mempelajari semua permasalahan politik Negara.

b. Demokrasi perwakilan

Dalam demokrasi perwakilan, seluruh rakyat memilih perwakilan melalui pemilihan umum untuk menyampaikan pendapat dan mengambil keputusan bagi mereka. Pokok atau gagasan dasar suatu pemerintahan demokrasi adalah pengakuan hakikat manusia, yaitu pada dasarnya manusia mempunyai kemampuan yang sama dalam hubungan sosial. Seiring dengan perkembangan-nya, Demokrasi menjadi suatu tatanan yangdi terima dan di pakai oleh hampir seluruh Negara di dunia. Ciri-ciri suatu pemerintahan demokrasi adalah sebagai berikut:

1) Adanya keterlibatan warga Negara dalam pegambilan keputusan politik, baik langsung maupun tidak langsung (perwakilan).

2) Adanya pengakuan, penghargaan, dan perlindungan terhadap hak-hak asasi rakyat (warga Negara).

3) Adanya persamaan hak bagi seluruh warga Negara dalam segala bidang.

4) Adanya lembaga peradilan dan kekuasaan kehakiman yang independen sebagai alat penegakan hukum.

5) Adanya kebebasan dan kemerdekaan bagi seluruh warga Negara.

6) Adanya pers (media massa) yang bebas untuk menyampaikan informasi dan mengontrol perilaku dan kebijakan pemerintah.

7) Adanya pemilihan umum untuk memilih wakil rakyat yang duduk dilembaga perwakilan rakyat. Adanya pemilihan umum yang bebas, jujur, adil untuk menentukan (memilih) pemimpin Negara dan pemerintahan serta anggota lembaga perwakilan rakyat.

8) Adanya pengakuan terhadap perbedaan keragaman (suku, agama, golongan, dan sebagainya).

\section{Sistem Kepartaian (Multi Partai)}

Sistem kepartaian pertama kali dibentangkan oleh Maurice Duverger dalam bukunya political parties. Duverger mengadakan klasifikasi menurut tiga teori, yaitu, sistem partai tunggal, sistem dwi partai, dan sistem multi partai. ${ }^{10}$

\footnotetext{
${ }^{10}$ Miriam Budiardjo. Dasar-Dasar Ilmu Politik. Jakarta: PT. Gramedia. 1991.
} 
Sistem kepartaian adalah pola kompetisi terus-menerus dan bersifat stabil, yang selalu tampak disetiap proses pemilu setiap Negara. Sistem kepartaian tergantung pada jenis sistem politik yang ada dalam suatu negara. Selain itu, ia juga bergantung kepada kemajmukan suku, agama, ekonomi, dan aliran politik yang ada. Semakin besar derajat perbedaan kepentingan yang ada di Negara tersebut, semakin besar pula jumlah partai politik.

Sistem multi partai adalah sistem kepartaian di mana di dalam Negara atau badan perwakilan terdapat lebih dari dua partai politik dan tidak ada satupun partai yang memegang mayoritas mutlak. Sistem multi partai dianggap lebih mencerminkan keanekaragaman budaya dan politik dibandingkan dengan sistem dua partai. Hal-hal yang mendorong berkembangnya sIstem multipartai adalah keanekaragaman komposisi masyarakat. Mengapa demikian?, Karena perbedaan-perbedaan ras, agama, dan suku merupakan faktor yang sangat kuat untuk menyatukan ikatan dalam satu wadah. Sistem multi partai lazimnya diperkuat oleh sistem pemilihan perwakilan berimbang yang memberi kesempatan luas untuk tumbuhnya partai-partai dan golongan-golongan kecil. Semenjak dimulainya orde reformasi, sistem pembatasan peserta pemilihan umum hanya dengan partai Golongan Karya dan dua partai politik diakhiri, Orde reformasi mengubahnya menjadi sistem multi partai dengan alasan untuk membuka seluasluasnya bagi keterwakilan seluruh golongan rakyat Indonesia. Jumlah partai pun membengkak menjadi puluhan seperti saat ini.

Adapun kelebihan dan kelemahan multi partai yaitu: Kelebihan multi partai :

a. Demokrasi berjalan dengan baik.

b. Inspirasi rakyat mampu menciptakan suatu partai.

c. Rakyat bebas bersuara.

d. Adanya oposisi antara partai satu dan yang lainnya.

Kelemahan multi partai:

a. Menimbulkan persaingan tidak sehat.

b. Saling menjatuhkan antara partai satu dan yang lainnya.

c. Banyaknya partai-partai politik dalam arti tidak sehat.

d. Dan berujung pada permusuhan dan perpecahan di antara partai satu dan yang lain. 


\section{Sistem Pemerintahan (Presidensial)}

Sistem pemerintahan dapat juga diartikan sebagai pembagian kekuasaan serta hubungan antar lembaga-lembaga Negara yang menjalankan kekuasaan-kekuasaan Negara tersebut dalam rangka penyelesaian kepentingan rakyat. Bintan R. Saragih mengartikan sistem pemerintahan sebagai keseluruhan dari susunan atau tatanan yang teratur dari lembaga-lembaga Negara yang berkaitan satu dengan yang lainnya baik langsung maupun tak langsung menurut rencana atau pola untuk mencapai tujuan Negara. ${ }^{11}$

Sistem pemerintahan Presidensial adalah sistem pemerintahan yang memegang kekuasaan eksekutif tidak harus bertanggungjawab kepada badan legislatif. Pemegang kekuasaan eksekutif terpisah dari badan legislatif. Presiden dalam sistem pemerintahan Presidensial dipilih untuk masa jabatan yang ditentukan dalam konstitusi suatu Negara dan tidak dapat dipaksa mengundurkan diri oleh badan legislatif, kecuali impeachment karena kepala Negara melakukan perbuatan yang bertentangan dengan konstitusi.

Dalam sistem pemerintahan Presidensial, Presiden memiliki kedudukan yang seimbang dengan legislatif maupun yudikatif. Karena antara ketiga cabang kekuasaan Negara terdapat hubungan secara horizontal, sehingga tidak dapat saling menjatuhkan kecuali dengan alasan yang ditentukan UUD. ${ }^{12}$

Ciri-ciri Sistem Pemerintahan Presidensial :

a. Presiden sebagai kepala Negara dan sebagai kepala pemerintahan.

b. Presiden tidak dipilih oleh badan perwakilan tetapi oleh dewan pemilih dan belakangan peranan dewan pemilih tidak tampak lagi.

c. Presiden bukan merupakan bagian dari lembaga legislatif.

d. Presiden tidak dapat dijatuhkan oleh badan legislatif, kecuali melalui dakwaan yang biasanya jarang terjadi.

e. Presiden tidak dapat membubarkan badan legislatif untuk kemudian memerintahkan pemilu baru.

f. Biasanya Presiden dan lembaga legislatif dipilih untuk suatu jangka waktu jabatan yang pasti. ${ }^{13}$

Chaidir E. Sistem Pemerintahan Negara Republik Indonesia Setelah Perubahan UUD 1945, dalam Sri Hastuti Puspitasari, Bunga Rampai Pemikiran Hukum di Indonesia. Yogyakarta: FH UII Press. 2009.

Jazim Hamidi M L. Hukum Lembaga Ke Presidenan Indonesia. Bandung: P.T. Alumni Bandung. 2010.

Huda N. Ilmu Negara. Jakarta: Rajawali Pers. (2011). 
Secara teoritik, sistem Presidensial dianggap tidak kompatibel dengan sistem multi partai. Alasannya, yang pertama, sistem multi partai meniscayakan adanya koalisi pemerintahan karena tidak adanya partai mayoritas dibadan legislatif. Koalisi itu sendiri dianggap sebagai karakteristik dari sistem parlementer. Kedua, dengan adanya koalisi politik, maka kekuasaan Presiden terpilih akan tersandera oleh kepentingan partai mitra koalisi, sehingga kekuasaan Presiden dianggap melemah dan pemerintahan berjalan tidak efektif karena terlalu banyak kompromi. Ketiga, sistem multi partai yang terfragmentasi cenderungan munculnya Presiden minoritas dengan dukungan legislatif yang lemah. Situasi ini dianggap akan menyebabkan sistem pemerintahan lumpuh. Agenda-agenda pemerintah dikhawatirkan hubungan eksekutif legislatif terancam mengalami kebuntuan. Karakteristik sistem Presidensial adalah badan perwakilan tidak memiliki supremacy of parliament karena lembaga tersebut bukan lembaga pemegang pemegang kekusaan Negara. Sebagai kepala pemerintahan dan satu-satunya kepala eksekutif, Presiden mengangkat dan memberhentikan menteri-menteri negara yang berfungsi sebagai pembantu Presiden dan memegang kekuasaan eksekutif dalam bidang masing-masing. Kabinet tidak bertanggungjawab, tetapi tiap-tiap menteri bertanggungjawab secara individu kepada Presiden. Berdasarkan uraian di atas maka penulis tertarik membahas permasalahan ini dengan judul : "Tinjauan Terhadap Sistem Multi Partai Dalam Sistem Pemerintahan Presidensial Di Indonesia Pada Era Reformasi”.

Berdasarkan uraian di atas maka memilih rumusan masalah sebagai berikut :

1. Bagaimanakah sistem multi partai yang berlaku dalam sistem pemerintahan Presidensial di Indonesia pada era reformasi?

2. Apakah implikasi penerapan sistem multi partai terhadap relasi eksekutif dan legislatif dalam sistem pemerintahan Presidensial yang berlaku di Indonesia pada era reformasi?

3. Bagaimanakah idealnya penerapan sistem multi partai dikaitkan dengan sistem pemerintahan Presidensial di Indonesia pada era reformasi? 


\section{METODE PENELITIAN}

\subsection{Jenis Penelitian}

Jenis penelitian / pendekatan yang yang digunakan oleh penulis adalah penelitian hukum normatif yaitu penelitian hukum kepustakaan ${ }^{14}$ karena menjadikan bahan kepustakaan sebagai tumpuan utama. Dalam penelitian hukum normatif ini penulis melakukan penelitian terhadap asas-asas hukum yang bertitik tolak dari bidang-bidang tata hukum tertentu, dengan cara mengadakan identifikasi terlebih dahulu terhadap kaidah-kaidah hukum yang telah dirumuskan di dalam perundang-undangan tertentu. Dalam konsep normatif, hukum adalah norma, baik yang diidentikkan dengan keadilan yang harus diwujudkan atau pun norma yang telah berwujud sebagai perintah yang eksplisit dan yang secara positif telah terumus jelas untuk menjamin kepastiannya, dan juga berupa normanorma yang merupakan produk dari seorang hakim pada waktu hakim memutuskan suatu perkara dengan memperhatikan terwujudnya kemanfaatan dan kemaslahatan bagi para pihak yang berpekara. ${ }^{15}$

\subsection{Metode dan Alat Pengumpulan Bahan Hukum}

Metode yang digunakan dalam penelitian ini adalah melalui studi kepustakaan/ studi dokumen, sehingga penelitian ini disebut penelitian hukum normatif dan data yang digunakan dalam penelitian ini adalah data sekunder yang dibedakan menjadi 3 (tiga) bagian, yaitu :

a. Bahan hukum Primer, yakni bahan-bahan ilmu hukum yang berhubungan erat dengan permasalahan yang diteliti, yaitu:

1) Undang - Undang Dasar Negara Republik Indonesia Tahun 1945.

2) Undang-Undang Nomor 31 Tahun 2002 tentang Partai politik.

3) Undang-Undang Nomor 10 Tahun 2008 tentang Pemilihan Umum Anggota Dewan Perwakilan Rakyat (DPR), Dewan Perwakilan Daerah (DPD), Dan Dewan Perwakilan Rakyat Daerah (DPRD).

b. Bahan Hukum Sekunder, yakni bahan-bahan hukum yang memberikan penjelasan atau membahas lebih hal-hal yang telah diteliti pada bahan-bahan hukum primer, yaitu :

Soerjono Soekanto, S. M. Penelitian Hukum Normatif, Suatu Tinjauan Singkat. Jakarta: PT. Raja Grafindo. 2003. Ashsofa B. Metode Penelitian Hukum. Jakarta: PT. Rineka Cipta. 1996. 
1) Buku mengenai Undang-Undang Dasar, pendapat-pendapat yang relavan dengan masalah yang diteliti serta data tertulis yang terkait dengan penelitian.

2) Berbagai makalah, jurnal, surat kabar, majalah, dokumen dan data-data dari internet yang berkaitan dengan penelitian.

c. Bahan Hukum Tertier, yakni bahan-bahan yang memberikan penjelasan terhadap bahan-bahan hukum Primer dan Sekunder, yakni Kamus Besar Bahasa Indonesia, Kamus Hukum dan ensiklopedi.

\section{HASIL PENELITIAN DAN PEMBAHASAN}

\section{Sistem Multi Partai Yang Berlaku Dalam Sistem Pemerintahan Presidensial Di}

\section{Indonesia Pada Era Reformasi.}

\section{a. Sistem Multi Partai di Indonesia Pada Era Reformasi.}

Pada era reformasi, sistem demokrasi di Indonesia memasuki era baru khususnya dengan munculnya sistem multi partai dalam pemilihan umum di Indonesia. Sistem multi partai ini dimaksudkan untuk menjamin semua partai politik dapat berpartisipasi dalam demokrasi. Bagi sejumlah Negara yang menerapkan atau mengklaim diri sebagai Negara demokrasi (berkedaulatan rakyat), pemilihan umum memang dianggap sebagai lambang sekaligus tolak ukur utama dan pertama dari demokrasi. Sistem kepartaian yang baik sangat menentukan bekerjanya sistem ketatanegaraan berdasarkan prinsip cheks and balances dalam arti yang luas. Sebaliknya, efektif bekerjanya fungsi-fungsi kelembagaan Negara itu sesuai prinsip cheks and balances berdasarkan konstitusi sangat menentukan kualitas sistem kepartaian dan mekanisme demokrasi yang dikembangkan suatu Negara. ${ }^{16}$

Upaya menyederhanakan sistem kepartaian antara lain dapat dilakukan dengan memperberat ketentuan pembentukan partai politik baru, yakni peningkatan persyaratan jumlah warga Negara yang dapat membentuk partai, dan pemberlakuan larangan bagi partai gagal electoral threshold (ET) untuk berganti nama sebagai partai baru.

\footnotetext{
16 Jimly Asshiddiqie. Menuju Negara Hukum Yang Demokrati. Jakarta: Sekretariat Jenderal Dan Kepaniteraan Mahkamah Konstitusi. 2008.
} 


\section{b. Sistem Pemerintahan Presidensial di Indonesia Pada Era Reformasi}

Gerakan mahasiswa pada tahun 1998 dengan mengatas namakan kedaulatan rakyat untuk mewujudkan demokratisasi yang kita kenal dengan Reformasi tersebut kemudian dimanifestasikan dengan perubahan UndangUndang Dasar 1945 melalui Amandemen Undang-Undang Dasar 1945, dimana Undang-Undang Dasar 1945 merupakan panduan sistem ketatanegaran Indonesia. Amandemen Undang-Undang Dasar 1945 sebenarnya selain merupakan manifestasi dari gerakan reformasi adalah hal yang seharusnya dilakukan melihat banyaknya kelemahan UndangUndang Dasar 1945 dan juga sifatnya yang sementara jika dilihat dari historis pembuatannya.

Di masa reformasi ini, berkembang aspirasi untuk lebih membatasi kekuasaan Presiden dengan menerapkan prinsip pemisahan kekuasaan yang tegas antara fungsi legislatif dan eksekutif itu. Sebelum amandemen Undang-Undang Dasar 1945 sistem pemerintahan Negara Kesatuan Republik Indonesia (NKRI) susah mengidentifikasinya sehingga ada yang berpendapat : menganut sistem pemerintahan Presidensial, sistem pemerintahan campuran bahkan sistem tersendiri yang disebut "sistem MPR". Tetapi pasca amandemen Undang-Undang Dasar 1945 sistem pemerintahan NKRI adalah sistem Presidensial murni.

2. Implikasi Penerapan Sistem Multi Partai Terhadap Relasi Eksekutif Dan Legislatif Dalam Sistem Pemerintahan Presidensial Yang Berlaku Di Indonesia Pada Era Reformasi.

a. Banyaknya kepentingan partai politik yang bertentangan dengan kebijakan pemerintah.

Dalam sistem politik seperti sekarang ini, partai politiklah yang banyak mewarnai kebijakan melalui wakil-wakilnya yang duduk dalam badan legislatif maupun eksekutif. Meskipun terdapat wakil-wakil nonpartai dalam parlemen seperti adanya Dewan Perwakilan Daerah (DPD), tetap saja wakil partailah yang mayoritas dan memegang peran utama dalam penyusunan undang-undang. ${ }^{17}$

Beberapa waktu yang lalu, Partai Keadilan Sejahtera (PKS) dan Partai Demokrati Indonesia Perjuangan (PDIP) pernah sama-sama menentang kebijakan pemerintah

Firmanzah. Marketing Politik. Jakarta: Yayasan Obor Indonesia. 2007. 
Susilo Bambang Yudhoyono (SBY) dalam menaikkan harga BBM. Kali ini, PKS akan siap bangun koalisi bersama lagi dengan PDIP untuk menolak kebijakan Presiden terpilih Joko Widodo dan Jusuf Kalla yang akan menaikkan harga BBM. Wakil Sekretaris Jenderal (Wasekjen) PKS Fahri Hamzah mengatakan, partainya akan konsisten menolak kenaikan harga BBM bersama partai pimpinan Megawati Soekarnoputri itu. Intinya ikut PDIP, tolak kenaikan BBM itu wujud koalisi kita dengan PDIP. Kali ini koalisi Merah Putih, dukung PDIP bahwa tolak kenaikan harga BBM. Diketahui, PDIP sebagai partai yang menentang keras soal kenaikan harga BBM diera pemerintahan Susilo Bambang Yudhoyono (SBY). PDIP beralasan, kenaikan harga BBM akan menyengsarakan seluruh lapisan masyarakat.

Dari kasus yang telah Penulis kemukakan diatas, bahwa implikasi dari penerapan sistem multi partai dalam sisem pemerintahan Presidensial di Indonesia terlihat pada banyaknya kepentingan partai politik yang bertentangan dengan kebijakan pemerintah.

\section{b. Tidak Adanya Pengaturan Koalisi Tetap.}

Di dalam sebuah sistem Presidensial dan multi partai membangun koalisi partai politik adalah hal yang umum yang terjadi. Koalisi partai politik terjadi karena untuk mendapatkan dukungan mayoritas dari parlemen merupakan sesuatu yang sangat sulit. Namun masalahnya adalah koalisi yang dibangun di dalam sistem Presidensial tidak bersifat mengikat dan permanen. Partai politik yang tergabung di dalam sebuah koalisi mendapat dukungan pemerintah bisa saja menarik dukungannya. Tidak adanya jaminan bahwa koalisi terikat untuk mendukung pemerintah sampai dengan berakhirnya masa kerja Presiden. Berdasarkan koalisi partai politik sistem pemerintahan Presidensial dengan sistem kepartaian multi partai yang menghadirkan banyak kesulitan dan masalah, berangkat dari design (desain) sistem pemilu Presiden yang berlaku, sulit menghindar dari pembentukan pemerintahan koalisi. Kita dapat melihat bahwa kesepakatan yang dibangun dalam Koalisi sangat bersifat umum sekali, bahwa setiap partai koalisi harus selalu mendukung pemerintah, maka hal ini sifatnya masih umum dan kabur, dan juga tidak ada ikatan didalamnya. Apabila mereka melakukan penghianatan terhadap koalisi pemerintahan, maka cukup sulit bagi pemerintah untuk menuntut atau tidak ada landasan hukum untuk mengatakan 
mereka berkhianat dan harus kembali pada kebijakan pemerintahan yang dibangun dalam Koalisi Partai Politik.

\section{c. Lemahnya Posisi Presiden}

Hal diatas juga menjadi indikasi sebagai bentuk pelemahan hak prerogatif Presiden dalam penyusunan kabinet. Profesionalisme yang seharusnya menjadi dasar pengisian jabatan pada Kementerian Negara, dilemahkan oleh pengaruh kekuatan partai mitra koalisi. Keadaan tersebut berakses pada kinerja pemerintahan yang terbentuk. Selain hal tersebut, koalisi yang terbentuk tidak menjadikan partai-partai yang tergabung ke dalam koalisi yang memiliki wakil di badan legislatif akan selalu mendukung programprogram pemerintahan. Padahal, salah satu tujuan dibentuknya koalisi adalah agar Presiden mendapat dukungan mayoritas badan legislatif untuk menghindari deadlock antara eksekutif dan legislatif dan serta immobilisasi dalam penyelenggaraan pemerintahan. Misalnya yang terjadi pada kasus Bank Century yang dapat menunjukkan lemahnya komitmen partai-partai yang menjadi mitra koalisi. Adanya imobilitas dan deadlock dalam sistem pemerintahan biasanya terjadi karena kurang kuatnya kedudukan kepala pemerintahan dalam suatu sistem politik di sebuah Negara.

\section{Penerapan Yang Ideal Terhadap Sistem Multi Partai Dikaitkan Dengan}

\section{Sistem Pemerintahan Presidensial Di Indonesia Pada Era Reformasi.}

\section{a. Penyederhanaan Partai Politik}

Sikap partai-partai politik di DPR yang lebih mendahulukan kepentingan partainya dari pada kepentingan untuk penguatan sistem pemilihan umum di Indonesia. Akibatnya, cita-cita untuk adanya keseimbangan antara pendalaman demokrasi dengan pengembangan kepemimpinan yang efektif dengan cara melakukan penyederhanaan jumlah peserta pemilihan umum tidak tercapai. Kedepan, semua partai politik harus konsisten dengan regulasi yang dibuat dan tidak merubah kembali tujuan dilakukannya penyederhanaan jumlah peserta pemilihan umum. Jika tidak, apalagi dengan terus menerus merubah aturan main pemilihan umum yang hanya ditujukan untuk kepentingan sesaat maka akan mengancam kehidupan demokrasi di Indonesia.

Dengan demikian proses-proses politik diparlemen menjadi lebih sederhana dan efisien dalam kerangka checks and balances yang proporsional. Apabila jumlah 
partai dalam lembaga parlemen sedikit berarti juga konfigurasi koalisi partai pendukung pemerintah semakin sedikit namun semakin kuat dan kokoh. Selain itu untuk menyederhanakan jumlah partai juga bisa dilakukan dengan menerapkan sistem campuran antara sistem distrik dan sistem proporsional dalam sistem pemilunya. Upaya tersebut semakin menjadi sempurna jika didukung oleh personalitas dan karakter kepemimpinan Presiden yang kuat dan tegas, sehingga tidak mudah untuk diintervensi dalam pembentukan kabinetnya.

\section{b. Pengaturan Koalisi Tetap}

Dalam sistem pemerintahan Presidensial yang multi partai, koalisi adalah suatu hal yang tidak bisa ditawar-tawar untuk membentuk pemerintahan yang kuat. Kinerja legislasi jauh dari mutu yang diharapkan karena banyaknya kepentingan politik kelompok yang berperan. Kondisi ini diperparah lagi dengan adanya kenyataan bahwa partai pendukung pemerintah tidak mampu menggalang dukungan mayoritas di parlemen. Akibatnya, stabilitas politik menjadi rendah dan berdampak pada tidak optimalnya pemerintah dalam merealisasikan programprogramnya. Oleh karenanya, koalisi pilpres dan di parlemen nanti diharapkan dapat meminimalkan risiko "gangguan parlemen" terhadap Presiden terpilih dalam menjalankan pemerintahannya. Dengan demikian koalisi adalah rekayasa institusional untuk mengurangi distorsi kombinasi Presidensial dan multi partai di satu pihak, dan dalam rangka efektivitas mengokohkan sistem Presidensialisme di pihak lain. Selain itu koalisi yang dibangun di parlemen dilakukan untuk memperkokoh dan menopang efektifitas kerja kabinet, serta untuk menjamin dukungan mayoritas di parlemen secara permanen, setidaknya untuk 5 (lima) tahun.

\section{c. Penguatan Institusi Kepresidenan}

Idealnya, untuk menjaga stabilitas pemerintahan dalam struktur politik Presidensial, partai Presiden haruslah partai mayoritas, yaitu partai yang didukung suara mayoritas di parlemen. Kekuatan mayoritas ini diperlukan dalam parlemen, untuk menjamin stabilitas pemerintahan Presiden terpilih agar Presiden mudah mendapatkan dukungan secara politik dari parlemen guna melancarkan kebijakan politik yang dibuat Presiden. Namun, suara mayoritas ini sulit diperoleh oleh partai Presiden dalam situasi multi partai, kecuali mengandalkan koalisi partai politik di 
parlemen dan kabinet agar dapat meraih suara mayoritas untuk menjamin stabilitas pemerintahan.

Diperlukan penguatan institusi kepresidenan yang diarahkan untuk memperkuat posisi politik Presiden di hadapan parlemen, agar kekuasaan parlemen tidak di atas Presiden, tetapi juga menghindari terlalu kuatnya posisi Presiden. Selain itu juga diarahkan kabinet solid dan pemerintahan dapat berjalan efektif. Karena itu, ada beberapa agenda rekayasa institusional, antara lain: penataan ulang sistem legislasi, Presiden tidak memiliki kekuasaan dalam membentuk Undang-Undang tetapi diberikan hak veto, kejelasan kewenangan wakil Presiden dan relasi antara Presiden dan wakil Presiden, dan aturan larangan rangkap jabatan bagi anggota kabinet.

\section{SIMPULAN DAN SARAN}

\subsection{Simpulan}

Dari pembahasan yang telah diungkapkan diatas, maka dapat ditarik kesimpulan mengenai sistem multi partai dalam sistem pemerintahan Presidensial di Indonesia pada era reformasi sebagai berikut:

1. Secara yuridis bahwa penerapan sistem multi partai di Indonesia tidak ada larangan. Sistem multi partai dalam pemilihan umum di Indonesia telah berkonsekuensi membludaknya partai politik yang ingin mengikuti pemilihan umum. Hal ini wajar karena reformasi telah terbuka peluang untuk pendirian partai-partai politik baru, namun demikian, pembatasan partai politik peserta pemilihan umum memang perlu dilakukan untuk memperkuat dan memperdalam demokrasi. Pembatasan ini pun bukan merupakan pelanggaran terhadap konstitusi. Oleh sebab itu, untuk di Indonesia, sistem Presidensial itu dapat dianggap kurang cocok untuk diterapkan dalam sistem banyak partai. Namun, karena bangsa Indonesia telah memasuki era demokratisasi yang menjamin kebebasan berserikat yang tidak mungkin lagi dihentikan, jumlah banyak partai juga tidak mungkin lagi dibatasi seperti pada masa Orde Baru. Oleh karena, diperlukan adanya mekanisme pengaturan yang menyebabkan jumlah partai politik itu secara alamiah dapat menciut dengan sendirinya tanpa adanya larangan ataupun pembatasan. 
2. Ada 3 (tiga) hal yang menjadi implikasi penerapan sistem multi partai terhadap relasi eksekutif-legislatif dalam sistem pemerintahan Presidensial di Indonesia pada era reformasi, yaitu: Pertama, banyaknya kepentingan partai politik yang bertentangan dengan kebijakan pemerintah. Kedua, tidak adanya pengaturan koalisi tetap. Ketiga, lemahnya posisi Presiden.

3. Idealnya penerapan sistem multi partai, agar terciptanya stabilitas sistem Presidensial di Indonesia, maka ada 3 (tiga) hal yang perlu dibenahi dalam sistem Presidensial kita, yaitu: Pertama, penyederhanaan partai politik, kedua, pengaturan koalisi tetap, dan ketiga, penguatan desain institusi kepresidenan.

\subsection{Saran}

Adapun saran yang dapat penulis berikan dalam tulisan ini adalah sebagai berikut:

1. Diperlukan adanya pelembagaan koalisi partai politik yang permanen, minimal koalisi partai politik itu untuk jangka waktu lima tahun.

2. Diperlukan adanya koalisi partai politik yang sifatnya permanen yang ditetapkan melalui aturanaturan Undang-Undang yang lebih jelas sehingga akan menghasilkan pemerintahan yang kuat dan efisien.

3. Diupayakan adanya penguatan institusi kepresidenan agar posisi Presiden tidak lemah terhadap Parlemen, dengan cara pemisahan institusi kepresidenan dari Dewan Perwakilan Rakyat (DPR) dan partai politik melalui aturanaturan undang-undang yang jelas.

\section{DAFTAR PUSTAKA}

Ashsofa B. Metode Penelitian Hukum. Jakarta: PT. Rineka Cipta, 1996.

Chaidir E. Sistem Pemerintahan Negara Republik Indonesia Setelah Perubahan UUD 1945, dalam Sri Hastuti Puspitasari, Bunga Rampai Pemikiran Hukum di Indonesia. 2009. Yogyakarta: FH UII Press.

Firmanzah. Marketing Politik. Jakarta: Yayasan Obor Indonesia. 2007.

Hayat. Korelasi Pemilu Serentak dengan Multi Partai Sederhana sebagai Penguatan Sistem Presidensial. Konstitusi, Sekretariat Jenderal Dan Kepaniteraan Mahkamah Konstitusi, Volume 11, 403. 2017.

Huda N. Ilmu Negara. Jakarta: Rajawali Pers. 2011.

Jazim Hamidi, M. L. Hukum Lembaga Ke Presidenan Indonesia. Bandung: P.T. 
Alumni Bandung. 2010.

Jimly Asshiddiqie. Menuju Negara Hukum Yang Demokrati. Jakarta: Sekretariat Jenderal Dan Kepaniteraan Mahkamah Konstitusi. 2008.

Mahfud MD M. Amandemen Konstitusi Menuju Reformasi Tata Negara. Yogyakarta: UII Press. 1999.

Mahmuzar. Sistem Pemerintahan Indonesia Menurut UUD 1945 Sebelum dan Sesudah Amandemen. Bandung: Nusa Media. 2010.

Miriam Budiardjo. Dasar-Dasar Ilmu Politik. Jakarta: PT. Gramedia. 1991.

Soerjono Soekanto S M. Penelitian Hukum Normatif, Suatu Tinjauan Singkat. Jakarta: PT. Raja Grafindo. 2003.

Tutik T T. Konstruksi Hukum Tata Negara Indonesia PascaAmandemen UUD 1945. Jakarta: Kencana. 2011.

Yuhana A. Sistem KetatanegaraanIndonesia Pasca Perubahan UUD 1945. Bandung: Fokus media. (2009).

Yulies Tiena Masriani. Pengantar Hukum Indonesia. Jakarta: Sinar Grafika. 2009.

Corina Auliya, R. F. F. (2017). www.dictio.id/t/jelaskan-mengenai-sistem-kepartaiandan klasifikasinya/12483. Klasifikasi Sistem Kepartaian. 